An Executive Committee, a Budget Committee and an External Relations Committee assist the Council although they have limited decision-making power within their fields of competence. In addition, the Executive Committee in Special Session meets, usually twice a year, and is attended by senior government officials. Most of the work of the OECD is prepared and carried out by about 250 specialized bodies (Committees, Working Parties, etc.). All members are normally represented on these bodies, except a few which have a more restricted membership. Funding is by member state contributions based on a formula related to their size and economy.

The International Energy Agency (IEA) and the Nuclear Energy Agency (NEA) are also part of the OECD system.

Headquarters: 2 rue André Pascal, 75775 Paris Cedex 16,

France.

Website: http://www.oecd.org

Secretary-General: Angel Gurría (Mexico).

Deputy Secretaries-General: Mari Kiviniemi (Finland),

Masamichi Kono (Japan).

Publications include: OECD Factbook (annual).-Economic, Environmental and Social Statistics (annual).-OECD Policy Briefs (20 a year).-OECD Economic Surveys (by country)._Environmental Performance Reviews (by country).-OECD Economic Outlook (twice a year).-Economic Policy Reform: Going for Growth (annual).-OECD-FAO Agricultural Outlook (annual).-Education at a Glance (annual).-OECD Employment Outlook (annual).-OECD Science, Technology and Industry Outlook (biennial).International Migration Outlook (annual).-Health at a Glance (biennial).-Society at a Glance (biennial)._OECD Health Statistics (online only).-Financial Market Trends (twice a year).-International Trade by Commodity Statistics (annual).-Main Economic Indicators (monthly).Energy Balances (annual)._World Energy Outlook (annual).-National Accounts (quarterly and annual). - African Economic Outlook (annual). OECD Observer (quarterly).-Development Co-operation Report (annual). For a full list of OECD publications, visit the website: http://www. oecdbookshop.org

\section{Organisation of Islamic Cooperation (OIC)}

Founded in 1969, the objectives of the OIC are to promote Islamic solidarity among member states; to consolidate cooperation among member states in the economic, social, cultural, scientific and other vital fields of activities, and to carry out consultations among member states in international organizations; to endeavour to eliminate racial segregation, discrimination and to eradicate colonialism in all its forms; to take the necessary measures to support international peace and security founded on justice; to strengthen the struggle of all Muslim peoples with a view to safeguarding their dignity, independence and national rights; to create a suitable atmosphere for the promotion of co-operation and understanding among member states and other countries. Originally known as the Organization of the Islamic Conference, it changed its name in June 2011.

Members (57 as of Feb. 2018). Afghanistan, Albania, Algeria, Azerbaijan, Bahrain, Bangladesh, Benin, Brunei, Burkina Faso, Cameroon, Chad, Comoros, Côte d'Ivoire, Djibouti, Egypt, Gabon, The Gambia, Guinea, Guinea-Bissau, Guyana, Indonesia, Iran, Iraq, Jordan, Kazakhstan, Kuwait, Kyrgyzstan, Lebanon, Libya, Malaysia, Maldives, Mali, Mauritania, Morocco, Mozambique, Niger, Nigeria, Oman, Pakistan, Palestine, Qatar, Saudi Arabia, Senegal, Sierra Leone, Somalia, Sudan, Suriname, Syria*, Tajikistan, Togo, Tunisia, Turkey, Turkmenistan, Uganda, United Arab Emirates, Uzbekistan, Yemen. Observers. Bosnia and
Herzegovina, Central African Republic, Russia, Thailand, Turkish Republic of Northern Cyprus. ${ }^{\star}$ Suspended since Aug. 2012.

Headquarters: PO Box 178, Jeddah 21411, Saudi Arabia.

Website: http://www.oic-oci.org

Secretary-General: Dr Yousef bin Ahmad Al-Othaimeen

(Saudi Arabia).

\section{Unrepresented Nations and Peoples Organization (UNPO)}

UNPO is an international organization created by nations and peoples around the world who are not represented in the world's principal international organizations, such as the UN. Founded in 1991, UNPO had 44 members as at Feb. 2018 representing more than $250 \mathrm{~m}$. people worldwide.

Membership. Open to all nations and peoples unrepresented, subject to adherence to the five principles that form the basis of UNPO's charter: equal right to self-determination of all nations and peoples; adherence to internationally accepted human rights standards; to the principles of democracy; promotion of nonviolence; and protection of the environment. Applicants must show that they constitute a 'nation or people' as defined in the Covenant.

Functions and Activities. UNPO offers an international forum for occupied nations, indigenous peoples, minorities and oppressed majorities, who struggle to regain their lost countries, preserve their cultural identities, protect their basic human and economic rights, and safeguard their environment.

It does not represent those peoples; rather it assists and empowers them to represent themselves more effectively. To this end, it provides professional services and facilities as well as education and training in the fields of diplomacy, human rights law, democratic processes, conflict resolution and environmental protection. Members, private foundations and voluntary contributions fund the Organization.

In total six former members of UNPO (Armenia, Belau, Estonia, Georgia, Latvia and Timor-Leste) subsequently achieved full independence and gained representation in the UN. Belau is now called Palau. Current members Bougainville and Kosovo have achieved a degree of political autonomy. Kosovo declared itself an independent state in 2008, although both Serbia and Russia oppose its sovereignty.

Headquarters: Avenue Louise 52, B-1050 Brussels, Belgium.

Website: http://www.unpo.org

Email: unpo@unpo.org

General Secretary: Marino Busdachin (Italy).

Publication. UNPO News (quarterly).

\section{World Council of Churches}

The World Council of Churches was formally constituted on 23 Aug. 1948 in Amsterdam. In Feb. 2018 member churches numbered 348 from more than 110 countries.

Origin. The World Council was founded by the coming together of Christian movements, including the overseas mission groups gathered from 1921 in the International Missionary Council, the Faith and Order Movement, and the Life and Work Movement. On 13 May 1938, at Utrecht, a provisional committee was appointed to prepare for the formation of a World Council of Churches. 